\title{
Experimental Comparative Study between Conventional and Green Parking Lots: Analysis of Subsurface Thermal Behavior under Warm and Dry Summer Conditions
}

\author{
Ryad Bouzouidja ${ }^{1}\left(\mathbb{D}\right.$, François Leconte ${ }^{2, *}{ }^{(0)}$, Márton Kiss ${ }^{3,4}$, Margaux Pierret ${ }^{5}$, Christelle Pruvot ${ }^{5}$, \\ Sébastien Détriché ${ }^{5}\left(\mathbb{D}\right.$, Brice Louvel ${ }^{5}$, Julie Bertout ${ }^{6}$, Zakaria Aketouane ${ }^{1}$, Tingting Vogt $\mathrm{Wu}^{1}{ }^{1}$, Rémy Goiffon ${ }^{7}$, \\ Baptiste Colin ${ }^{2}$, Anélie Pétrissans ${ }^{2}$, Philippe Lagière ${ }^{1}$ and Mathieu Pétrissans ${ }^{2} \mathbb{C}$
}

check for updates

Citation: Bouzouidja, R.; Leconte, F.; Kiss, M.; Pierret, M.; Pruvot, C.; Détriché, S.; Louvel, B.; Bertout, J. Aketouane, Z.; Vogt Wu, T.; et al. Experimental Comparative Study between Conventional and Green Parking Lots: Analysis of Subsurface Thermal Behavior under Warm and Dry Summer Conditions. Atmosphere 2021, 12, 994. https://doi.org/ $10.3390 /$ atmos12080994

Academic Editors: Dragan Milosevic, Britta Jänicke, Yuliya Dzyuban and Michael Allen

Received: 7 July 2021

Accepted: 29 July 2021

Published: 31 July 2021

Publisher's Note: MDPI stays neutral with regard to jurisdictional claims in published maps and institutional affiliations.

Copyright: (c) 2021 by the authors. Licensee MDPI, Basel, Switzerland. This article is an open access article distributed under the terms and conditions of the Creative Commons Attribution (CC BY) license (https:// creativecommons.org/licenses/by/ $4.0 /)$
1 Université de Bordeaux, CNRS UMR 5295, I2M Bordeaux, 351 Cours de la Libération, 33400 Talence, France ryad.bouzouidja@gmail.com (R.B.); aketouane@gmail.com (Z.A.); tingting.vogt-wu@u-bordeaux.fr (T.V.W.); philippe.lagiere@u-bordeaux.fr (P.L.)

2 INRAE, LERMaB, Université de Lorraine, 88000 Epinal, France; baptiste.colin@univ-lorraine.fr (B.C.); anelie.petrissans@univ-lorraine.fr (A.P.); mathieu.petrissans@univ-lorraine.fr (M.P.)

3 Centre for Ecological Research, Institute of Ecology and Botany, H-2163 Vácrátót, Hungary; kiss.marton@geo.u-szeged.hu

4 Department of Climatology and Landscape Ecology, University of Szeged, 2 Egyetem Str., H-6722 Szeged, Hungary

5 Junia, Université de Lille, Université d'Artois, IMT Lille Douai, ULR 4515-LGCgE, Laboratoire de Génie Civil et Géo-Environnement, 59000 Lille, France; mpierret@jeunes-agriculteurs.fr (M.P.); christelle.pruvot@junia.com (C.P.); sebastien.detriche@junia.com (S.D.); brice.louvel@junia.com (B.L.)

6 O2D Environnement, 117 Rue Pierre Brizon, 59810 Lesquin, France; jbertout@o2d.fr

7 Ecole Nationale Supérieure d'Architecture et de Paysage de Bordeaux, Laboratoire GRECCAU,

740 Cours de la Libération, CS 70109, CEDEX, 33405 Talence, France; remy.goiffon@bordeaux.archi.fr

* Correspondence: francois.leconte@univ-lorraine.fr

Abstract: Green infrastructure has a role to play in climate change adaptation strategies in cities. Alternative urban spaces should be designed considering new requirements in terms of urban microclimate and thermal comfort. Pervious pavements such as green parking lots can contribute to this goal through solar evaporative cooling. However, the cooling benefits of such systems remain under debate during dry and warm periods. The aim of this study was to compare experimentally the thermal behavior of different parking lot types (PLTs) with vegetated urban soil. Four parking lots were instrumented, with temperature probes buried at different depths. Underground temperatures were measured during summer 2019, and the hottest days of the period were analyzed. Results show that the less mineral used in the surface coating, the less it warms up. The temperature difference at the upper layer can reach $10{ }^{\circ} \mathrm{C}$ between mineral and non-mineral PLTs. PLTs can be grouped into three types: (i) high surface temperature during daytime and nighttime, important heat transfer toward the sublayers, and low time shift (asphalt system); (ii) high (resp. low) surface temperature during daytime (resp. nighttime), weak heat transfer toward the sublayers, and important time shift (paved stone system); and (iii) low surface temperature during daytime and nighttime, weak heat transfer toward the sublayers, and important time shift (vegetation and substrate system, wood chips system, vegetated urban soil). The results of this study underline that pervious pavements demonstrate thermal benefits under warm and dry summer conditions compared to conventional parking lot solutions. The results also indicate that the hygrothermal properties of urban materials are crucial for urban heat island mitigation.

Keywords: green infrastructure; green parking lot; in-situ measurement; nature-based solutions; pervious pavement; soil temperature 


\section{Introduction}

The urban heat island (UHI) phenomenon is triggered by several factors, such as the specific urban land cover, the canyon-shaped infrastructure morphology, the anthropogenic heat emissions, and the physical properties of the urban materials [1,2]. Many studies focus on identifying different patterns of urban expansion and their consequences on the urban microclimate [3-6]. Cai et al. [3] studied the influence of urbanization on the urban climate. They observed that the arrangement of urban areas in relation to water and vegetated areas affects energy fluxes. Several methods are proposed for reporting different types of land use. A major approach is the use of land cover indices [7,8], followed by the classification methods [9]. Jalan and Sharma [10] used land surface temperature (LST) to quantify the spatiotemporal changes in the UHI of Jaipur city (India). They found that urbanization affects the LST by about $3^{\circ} \mathrm{C}$.

Urbanization processes tend to increase the fraction of sealed and impervious surfaces. However, urban facets significantly influence the urban climate. Urban facets often demonstrate specific hygrothermal properties (e.g., low albedo, and reduced water absorption and retention), which lead to extreme surface temperature.

The development of sustainable and resilient cities requires alternative solutions and concepts, such as nature-based solutions (NBS) or green infrastructure (GI) [11]. Zölch et al. [12] reported that GI affects pedestrians' thermal comfort. They conducted a study on high-density residential areas under current and future climatic conditions. GI (planting trees) demonstrates the strongest impact with an average physiological equivalent temperature (PET) reduction of $13 \%$ compared with existing vegetation. At ground level, several new pavement technologies are emerging, including pavement watering, reflective pavement, pervious pavement, and heat storage pavement [13].

Green parking lots (GPLs) are now being suggested as potential solutions for urban water management and UHI mitigation [14]. Onishi et al. [14] studied the influence of vegetation on urban parking in Nagoya city, Japan, during the warm period (spring and summer). They showed that parking with grass slightly reduced the LST (maximum LST decreased by $7.26^{\circ} \mathrm{C}$ in the summer for one GPL). Park et al. [15] conducted a study of GPLs in Ulsan, Korea. They observed that the replacement of pavement materials reduces the radiant temperature of the surface. Considering the anthropogenic nature of its soil layers, a GPL can be considered as an urban soil or Technosol [16]. Pervious GPL systems included porous layers that retain water. Evaporation of stored water contributes to a cooling down perception for pedestrians and a sensible reduction of air ambient temperature [17]. In addition, GPLs could reduce surface temperature if vegetation is included [18].

Several studies show the importance of vegetation and biobased materials (e.g., wood chips) on the GPL behavior [19]. Wood chips may be locally produced and originate from sustainably managed forest. In addition, Buchanan et al. [20] argued that wood chips can be a solution adapted to the urban context because of their effectiveness in controlling soil erosion on a steeply sloping construction site.

Wang et al. [21] presented two types of driving factors for the evaporative cooling performance of pervious materials, namely the climatic parameters [22] and the hygrothermal parameters (albedo, water absorption, and water retention properties) [23]. Solar radiation has been reported to be the most significant climatic parameter, followed by air temperature, relative humidity, and wind speed [22].

Hygrothermal properties of pervious pavement are usually assessed under controlled conditions [24]. However, performance observed during laboratory experimental tests must be consolidated with summertime case studies of pervious pavement implemented at full scale. During dry and warm periods, water availability within pervious pavements may shrink dramatically. In these conditions, evaporation may be strongly reduced, and the cooling benefits of GPLs may be weakened. In the case of pervious concrete, Nemirovsky et al. [25] suggest that water stored far from the surface does not participate in the evaporation process. 
Previous studies have shown that, without precipitation, pervious pavements may increase the urban overheating due to their high specific heat capacity and reduced evaporation [26]. Therefore, thermal performance of full-scale GPLs needs to be analyzed to investigate the extent to which pervious pavements can be considered as heat sinks during warm and dry periods. This study aimed to analyze experimentally the thermal behavior of four full-scale parking lot systems under dry and warm summer conditions. To highlight the thermal dynamics and the heat transfer patterns between the different layers, heat and cooling rates were calculated.

This analysis is organized as follows. Section 2 illustrates the study area, data, and methods. It also presents the design of the studied GPL. Section 3 analyzes and discusses the characteristics of the GPLs in terms of thermal performances.

\section{Materials and Methods}

\subsection{Study Site}

This study was conducted in northern France within the conurbation of Lille (Figure 1A). It is the sixth largest French conurbation and has 1,100,000 inhabitants. Located approximately $50 \mathrm{~km}$ south of the North Sea, Lille experiences a temperate oceanic climate (Cfb climate in the Köppen Geiger classification system [27]). July is the warmest month of the year, with an average maximal (resp. minimal) air temperature of $23.3^{\circ} \mathrm{C}$ (resp. $13.8^{\circ} \mathrm{C}$ ) [28]. July is also the wettest month of the summer, with $68.5 \mathrm{~mm}$ of precipitation on average. The mean month insolation values for June, July, and August are, respectively, 206, 211, and $199 \mathrm{~h}[28]$.

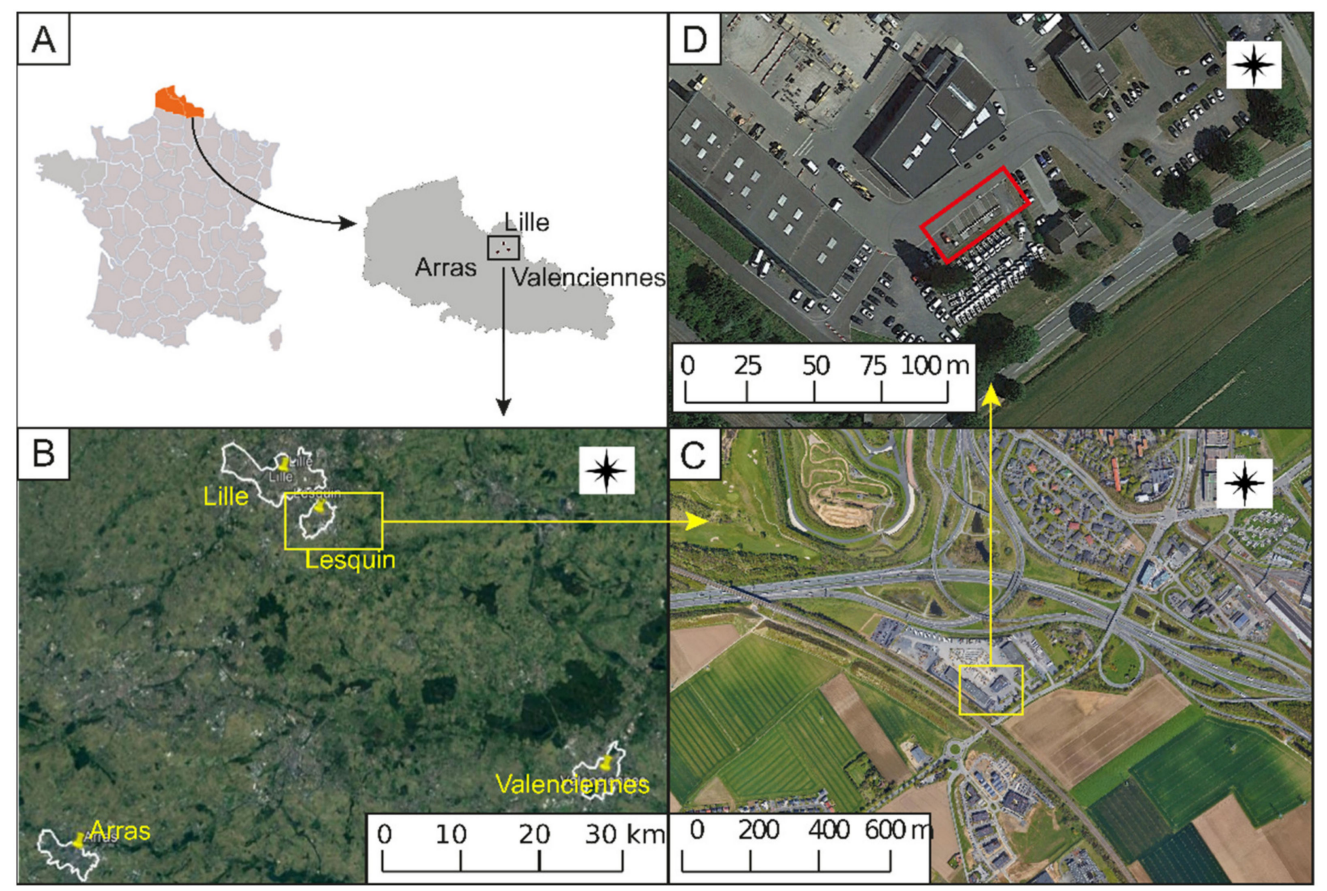

Figure 1. (A) Location of the cities of Lille, Arras, and Valenciennes (France); (B) location of the city of Lesquin compared to Arras and Valenciennes cities; (C) aerial view of the experimental site environment (location of the platform marked with a black box); (D) location of the studied parking lots (sources: Google Earth).

To date, the urban climate of Lille has been little investigated; therefore, data to estimate the amplitude of Lille's UHI are scarce. However, under a calm and clear sky, several values of the UHI amplitude are available for nearby cities with a similar background climate: $4.4^{\circ} \mathrm{C}$ for Nancy, France (conurbation population: 286,000 inhabitants) [29]; a maximum of $6^{\circ} \mathrm{C}$ for Ghent, Belgium (conurbation population: 560,000 inhabitants) [30]; and up to $8^{\circ} \mathrm{C}$ for Paris, France (conurbation population: 10,800,000 inhabitants) [31]. 
According to these results and to the conurbation size, the UHI amplitude of Lille could be estimated to be between 4 and $7{ }^{\circ} \mathrm{C}$ under a calm and clear sky.

The studied parking lots are situated in the city of Lesquin $\left(50^{\circ} 34^{\prime} 56.35^{\prime \prime} \mathrm{N} 3^{\circ} 07^{\prime} 8.40^{\prime \prime} \mathrm{E}\right)$, in the southern part of the conurbation (Figure 1B). At the local scale, the experimental site belongs to a small industrial settlement, which was built between a highway and agricultural fields (Figure 1C,D).

\subsection{Structure and Composition of Studied Parking Lots}

Eight parking places were built on the Experimental Platform (EP) of Lesquin by construction companies (Figure 2). Due to technical issues, data are available for only four parking lots. The composition of the parking lots is presented in Figure 3 and in Table 1.

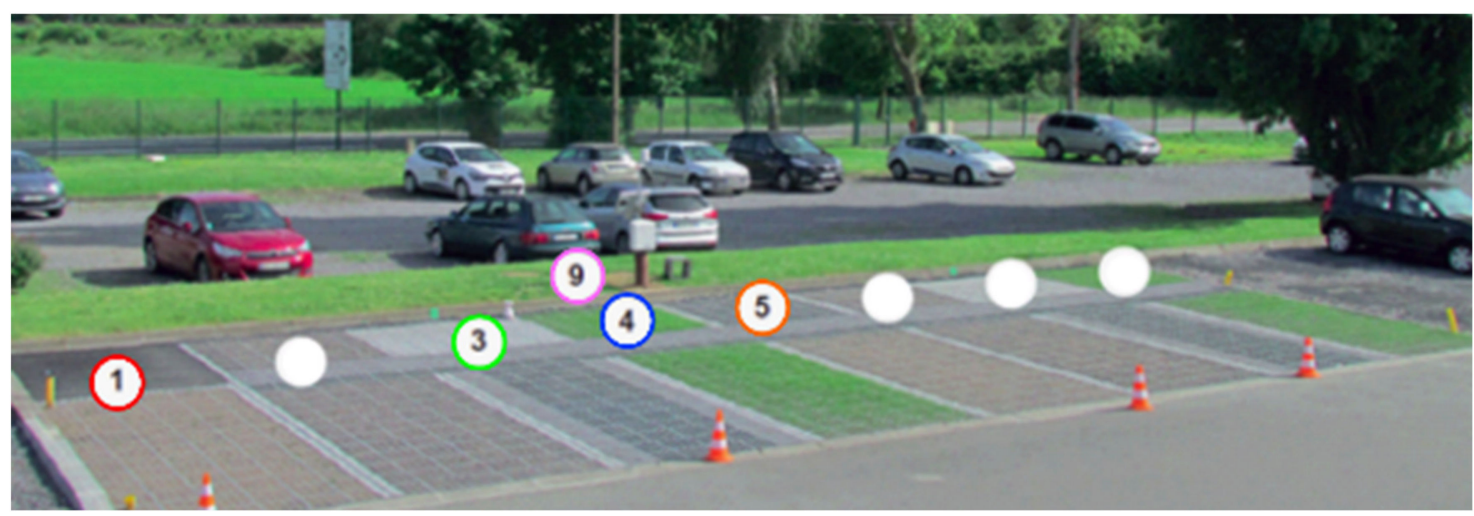

Figure 2. View of the experimental site. Studied parking lots are 1 (red round), 3 (green round), 4 (blue round), 5 (orange round), and control zone 9 (pink round). The other parking lots were not considered due to experimental issues.

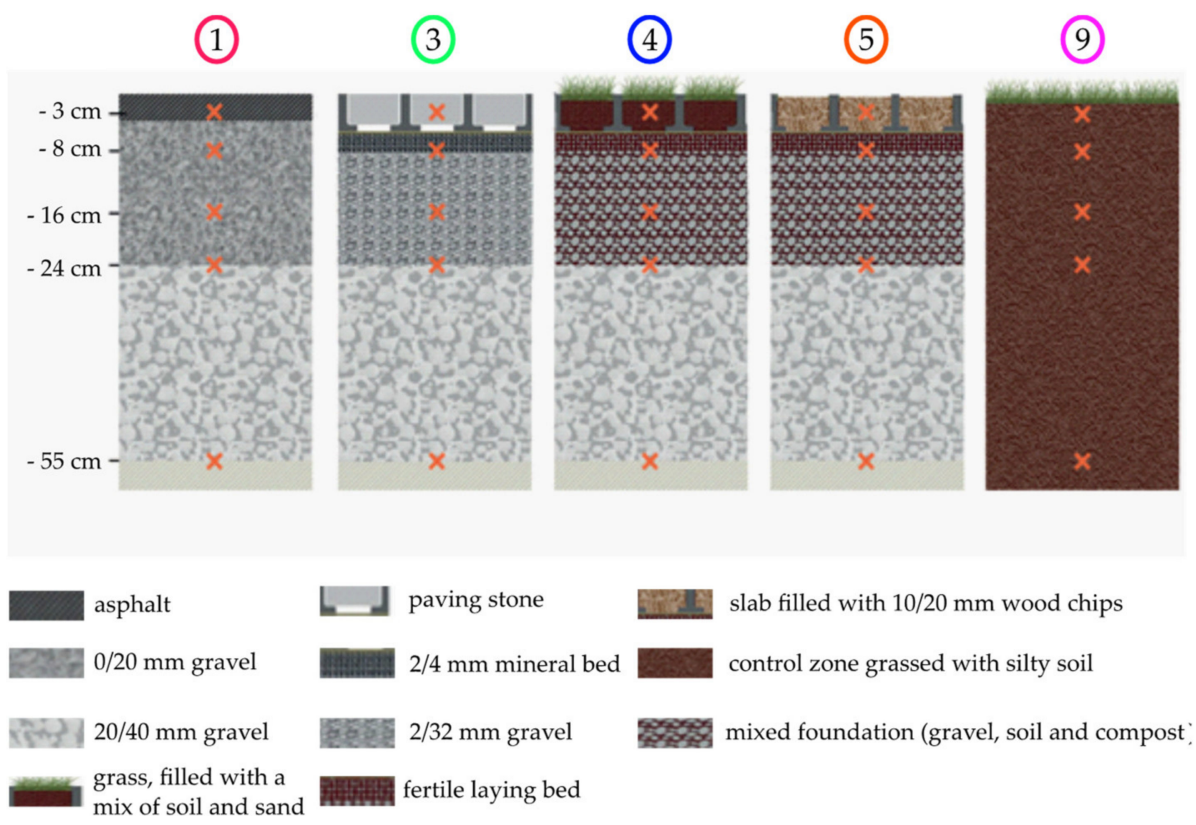

Figure 3. Composition of the Parking Lot Types (PLTs): asphalt (P1), concrete paving stone (P3), vegetation and soil (P4), wood chips (P5), and control zone (CZ9). The red crosses indicate the positions of thermal sensors. 
Table 1. Description of the four parking lots (P) and the control zone (CZ9).

\begin{tabular}{|c|c|c|c|c|c|c|}
\hline \multirow{2}{*}{ Material } & \multirow{2}{*}{ Composition } & \multicolumn{5}{|c|}{ Plot Type-Thickness } \\
\hline & & P1 & P3 & $\mathbf{P 4}$ & P5 & CZ9 \\
\hline Asphalt & (ASP) & $5 \mathrm{~cm}$ & - & - & - & - \\
\hline $\begin{array}{l}\text { Slab filled with concrete } \\
\text { paving stone }\end{array}$ & (SPS) & - & $6 \mathrm{~cm}$ & - & - & - \\
\hline Slab with mix soil and sand & $\begin{array}{l}90 \% \text { of soil and compost } 0 / 10 \mathrm{~mm}, 10 \% \text { of sand } \\
0 / 4 \mathrm{~mm} \text { (SCS) }\end{array}$ & - & - & $5 \mathrm{~cm}$ & - & - \\
\hline Slab filled with wood chips & $10 / 20 \mathrm{~mm}$ wood chips (SWC) & - & - & - & $5 \mathrm{~cm}$ & - \\
\hline Grass & $(\mathrm{GRA})$ & - & - & $x$ & - & $x$ \\
\hline Mineral bed & $2 / 4 \mathrm{~mm}(\mathrm{MB})$ & - & $3 \mathrm{~cm}$ & - & - & - \\
\hline \multirow[t]{2}{*}{ Fertile laying bed } & $\begin{array}{l}60 \% \text { gravel } 4 / 6 \mathrm{~mm}+20 \% \text { sand } 0 / 4 \mathrm{~mm}+20 \% \\
\text { soil and compost } 0 / 10 \mathrm{~mm}(\mathrm{SSC})\end{array}$ & - & - & $3 \mathrm{~cm}$ & $3 \mathrm{~cm}$ & - \\
\hline & Gravel 0/20 mm* (G0/20) & $15 \mathrm{~cm}$ & - & - & - & - \\
\hline \multirow[t]{2}{*}{ Foundation } & Gravel 2/32 mm + (G2/32) & - & $15 \mathrm{~cm}$ & - & - & - \\
\hline & $75 \%$ of gravel, $25 \%$ of soil and compost (GSC) ${ }^{\dagger}$ & - & - & $15 \mathrm{~cm}$ & $15 \mathrm{~cm}$ & - \\
\hline Subfoundation & Gravel 20/40 mm (G20/40) & $20 \mathrm{~cm}$ & $20 \mathrm{~cm}$ & $20 \mathrm{~cm}$ & $20 \mathrm{~cm}$ & - \\
\hline
\end{tabular}

* represents information about P1. + represents information about P3. + represents information about P5.

The control zone CZ9 is defined as a grass-covered area with silty soil (thickness $55 \mathrm{~cm}$ ). The four parking lot systems (P1, P3, P4, and P5) are laid on a subfoundation of $20 / 40 \mathrm{~mm}$ gravel (thickness $20 \mathrm{~cm}$ ). Their composition and structure are described from upper layer to deeper layer:

- The parking lot P1 is a conventional system composed of asphalt (thickness $5 \mathrm{~cm}$ ) with a $0 / 20 \mathrm{~mm}$ gravel foundation (thickness $15 \mathrm{~cm}$ ).

- $\quad$ The parking lot $\mathrm{P} 3$ is composed of a slab filled with concrete paving stones (thickness $6 \mathrm{~cm}$ ), a $2 / 4 \mathrm{~mm}$ mineral bed (thickness $3 \mathrm{~cm}$ ), and a $2 / 32 \mathrm{~mm}$ gravel foundation (thickness $15 \mathrm{~cm}$ ).

- P4 is built up of a grass-covered slab filled with a mix of soil and sand $(90 \%$ soil and compost, $10 \%$ sand $0 / 4 \mathrm{~mm}$, thickness $6 \mathrm{~cm}$ ), a fertile laying bed $(60 \%$ sand, $20 \%$ sand $0 / 4 \mathrm{~mm}$, and $20 \%$ soil and compost $0 / 10 \mathrm{~mm}$, thickness $3 \mathrm{~cm}$ ) and a mixed foundation (75\% gravel, $25 \%$ soil and compost, thickness $15 \mathrm{~cm}$ ).

- $\quad$ P5 is composed of a slab filled with $10 / 20 \mathrm{~mm}$ wood chips (forest mulch, thickness $5 \mathrm{~cm})$, a fertile laying bed $(70 \%$ sand, $30 \%$ soil and compost, thickness $3 \mathrm{~cm})$, and a mixed foundation ( $75 \%$ gravel, $25 \%$ soil and compost, thickness $15 \mathrm{~cm}$ ).

The slab is a plastic structure made of recycled polypropylene and polyethylene, which provides the required mechanical properties for parking lot use (Figure 4). It represents approximately $39 \%$ of the total surface of the parking lot.

Table 1 summarizes the information of the four PLs and CZ9, and Tables 2 and 3 present the physical properties of the studied materials.

\subsection{Materials}

Probes were placed during the construction phase of the four parking lots. Different depths were chosen to analyze different construction materials (filling, bedding, foundation, and subfoundation).

Five probes were installed in each of the four parking lots and in an adjacent grassed area (control zone, CZ9). Two types of thermal probes were used: Campbell Scientific CS107 (temperature accuracy of $\pm 0.4{ }^{\circ} \mathrm{C}$ ) probes were buried at depths of $-3,-8,-24$, and $-55 \mathrm{~cm}$; and Campbell Scientific CS255 (temperature accuracy of $\pm 0.4{ }^{\circ} \mathrm{C}$ ) probes were buried at $-16 \mathrm{~cm}$ (Figures 3 and 4). The probes were located in the center of the parking lot, assuming that this center point was not affected by other adjacent parking lots. The width of the parking lot was $2.4 \mathrm{~m}$. The distance between the center of a given parking lot and an adjacent parking lot was $1.2 \mathrm{~m}$. 


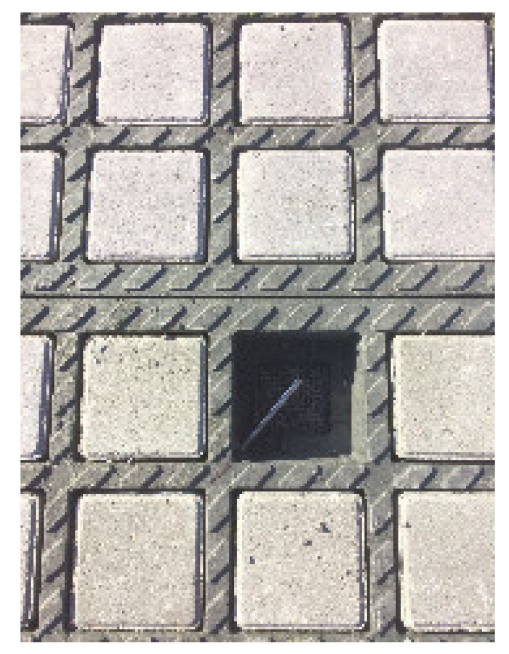

Figure 4. Example of sensor position at a depth of $3 \mathrm{~cm}$ in concrete paving stones (CS107). The sensor was placed inside a paving stone.

Table 2. Description of the four parking lots (PLs) and the control zone (CZ9).

\begin{tabular}{|c|c|c|c|c|c|}
\hline Material & Thermal Conductivity & Heat Capacity & Emissivity & Albedo & Ref. \\
\hline Unit & $\left(\mathrm{W} \mathrm{m} \mathrm{m}^{-1} \mathrm{~K}^{-1}\right)$ & $\left(\mathrm{J} \mathrm{kg}^{-1} \mathrm{~K}^{-1}\right)$ & $(-)$ & $(-)$ & \\
\hline ASP & 0.88 & $1094-1203$ & 0.99 & 0.15 & {$[32,33]$} \\
\hline SPS & 0.85 & $2200-2800$ & 0.99 & 0.178 & {$[34,35]$} \\
\hline SCS & & $810-973$ & 0.92 & 0.39 & [34] \\
\hline SWC & 0.07 to 0.08 & - & - & - & [36] \\
\hline GRA & - & - & $0.90-0.96$ & $0.18-0.22$ & {$[37]$} \\
\hline MB & - & - & ND & ND & - \\
\hline SSC & - & - & ND & ND & - \\
\hline $\mathrm{G} 0 / 20$ & $0.38-1.1$ & ND & ND & ND & [38] \\
\hline $\mathrm{G} 2 / 32$ & $0.38-1.1$ & ND & ND & ND & {$[38]$} \\
\hline GSC & $1.6-2.1$ & ND & ND & ND & [39] \\
\hline $\mathrm{G} 20 / 40$ & $0.38-1.1$ & ND & ND & ND & [38] \\
\hline Soil & $0.073-0.203$ & ND & ND & ND & [40] \\
\hline
\end{tabular}

Table 3. Physical properties of aggregates.

\begin{tabular}{ccccc}
\hline Properties & Asphalt (ASP) & Paving Stone & Fertile Laying Bed (SSC) & Mineral Bed (MB) \\
\hline Maximum diameter $(\mathrm{mm})$ & 8 & 1 & 6 & 4 \\
Bulk density $\left(\mathrm{kg} \mathrm{m}^{-3}\right)$ & 8 & 2292 & 1300 & 1600 \\
Solid density $\left(\mathrm{kg} \mathrm{m}^{-3}\right)$ & 2350 & 2527 & 2900 & 2660 \\
Bitumen content $(\%)$ & $5-6$ & N/A & N/A & N/A \\
\hline
\end{tabular}

Table 2 summarizes the physical properties of the constituent materials of the four GPLs and the CZ9.

Outdoor temperature and relative humidity probes (Campbell Scientific CS215) and a rain gauge (Campbell Scientific Kalyx-RG, Loughborough, UK) were also installed. These sensors were connected to a data logger (Campbell Scientific CR1000 $\times$ Series) powered by a battery connected to a solar panel (Campbell Scientific SP30) (Figure 5). Temperature values were recorded with a 5-min time step between 1 June 2019 and 31 August 2019. 


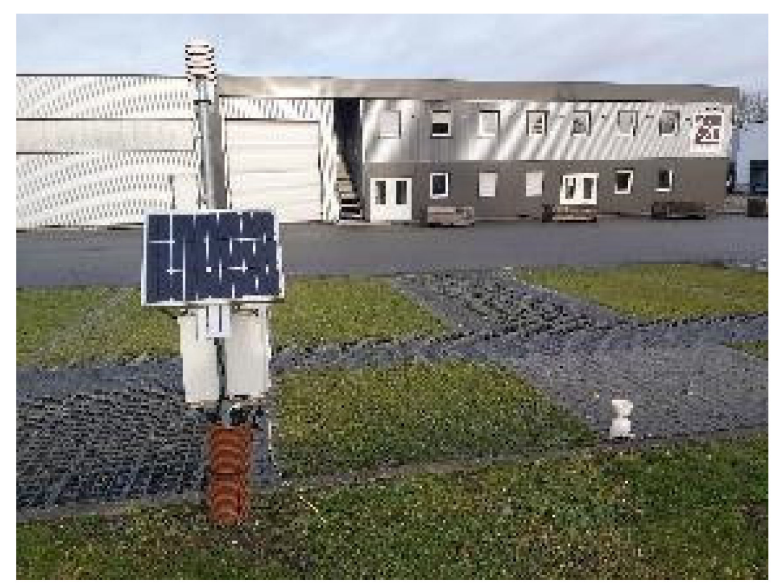

Figure 5. Data acquisition facility: outdoor temperature and relative humidity probe (CS215) on the left, rain gauge on the right (Kalyx-RG).

\subsection{Key Performance Indicators of Parking Lot Dynamics}

To evaluate the dynamics of the parking lots, several key performance indicators were used. Hourly variation of underground temperature between 1 June 2019 and 31 August 2019 was analyzed. The temperature difference with respect to the control zone (CZ9) was calculated (Equation (1)). The $\Delta T$ experimental error was $\pm 0.8^{\circ} \mathrm{C}$ based on the temperature measurement:

$$
\Delta T=\left(T_{j c m}\right)_{P i}-\left(T_{j c m}\right)_{C Z}
$$

where $T_{j \mathrm{~cm}}$ is the temperature $\left({ }^{\circ} \mathrm{C}\right)$ at each depth $j=-3,-8,-16,-24,-55 \mathrm{~cm}$, for each parking lot $P i=1,3,4,5$.

The rate of change (RC) was considered to investigate the thermal behavior of the parking lots over time, because this approach has been adopted in previous urban climate studies [41-44]. The analysis was based on the sixty-minute average temperature to calculate the hourly $\operatorname{RC}\left({ }^{\circ} \mathrm{Ch}^{-1}\right)$ (Equations (2) and (3)):

$$
R C=\frac{T_{\text {mean }}}{t}
$$

where $T_{\text {mean }}\left({ }^{\circ} \mathrm{C}\right)$ is the average temperature during the previous $60 \mathrm{~min}$ and $t$ is time (hour). $T_{\text {mean }}$ was used to calculate $R C$. The $R C$ experimental error was $\pm 0.4^{\circ} \mathrm{C} \mathrm{h}^{-1}$ based on the temperature measurement.

The standard deviation function was also used. This expresses the dispersion of a dataset relative to its mean [45]:

$$
S_{d}=\sqrt{\frac{\left(\sum x_{i}-\mu\right)^{2}}{N}}
$$

where $S_{d}$ is the population standard deviation, $N$ is the size of the population, $x_{i}$ is the value from the population, $\mu$ is the population mean.

\subsection{Local Air Temperature and Rainfall Observations}

Data (outdoor temperature and rainfall quantity) from the weather station were obtained over a 3-month period from June to August 2019 (Figure 6). During this period, the outdoor temperature was particularly high and set new records $[46,47]$. The air temperature varied from 7.7 to $41.0^{\circ} \mathrm{C}$, with an average value of $19.2^{\circ} \mathrm{C}$, and a total rainfall of $7.4 \mathrm{~mm}$. The end of June 2019 demonstrated very warm weather. The outdoor temperature reached $35.2^{\circ} \mathrm{C}$ on 29 June. This period (24 June-1 July 2019) was selected to evaluate the thermal 
behavior of the GPLs during very warm weather. RC was analyzed during the warmest period of summer 2019 (25-26 June 2019).

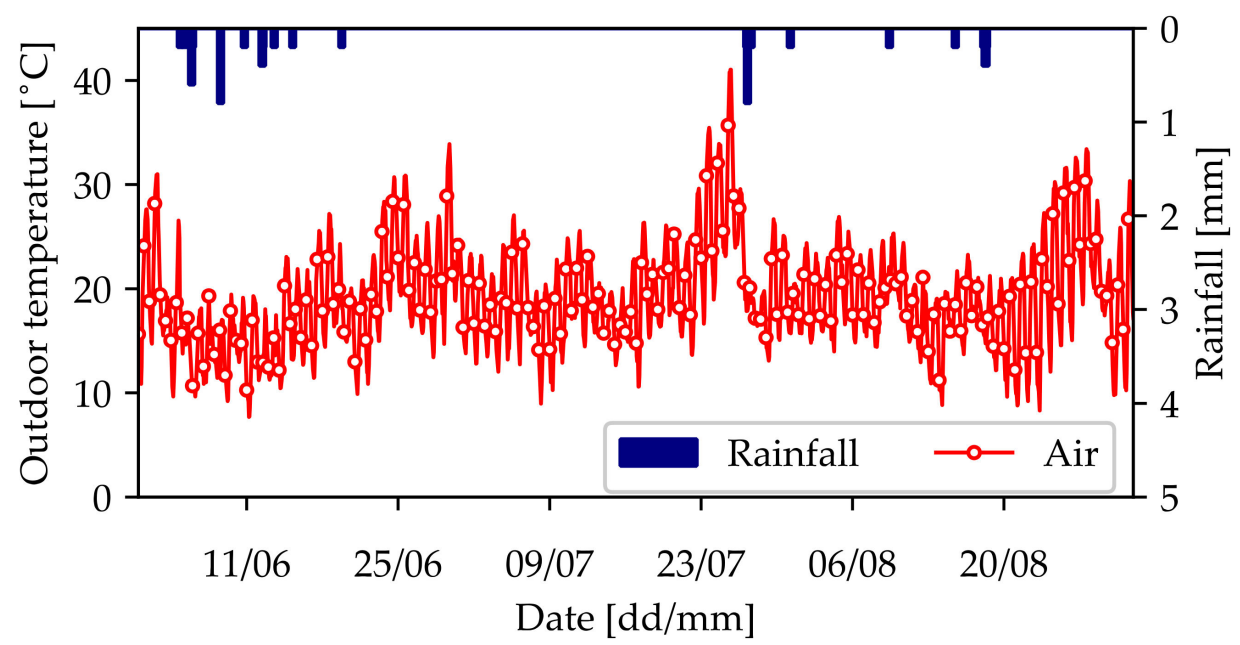

Figure 6. Hourly variation of outdoor temperature (red continuous lines with round markers- ${ }^{\circ} \mathrm{C}$ ) and rainfall (dark blue histogram $-\mathrm{mm}$ ) measured by the experimental platform weather station between 1 June 2019 and 30 August 2019.

Figure 7 compares the air temperature measurements from the Experimental Platform (EP) presented in Figure 5 with the nearby weather station operated by Météo France (MF), located at Lesquin Airport. The Lesquin MF weather station is part of the national weather observation network, and is located $4 \mathrm{~km}$ from the EP. It appears that the EP air temperature and the air temperature from the MF weather station of Lesquin were similar during the analysis period $\left(\mathrm{S}_{\mathrm{d}-\mathrm{MF} \text { Lesquin }}=4.53{ }^{\circ} \mathrm{C}\right.$ and $\mathrm{S}_{\mathrm{d}-\mathrm{EP}}=4.41^{\circ} \mathrm{C}$ ) (Figure $\left.7 \mathrm{a}\right)$. Figure $7 \mathrm{~b}$ shows that the correlation between the two temperature datasets was strong $\left(R^{2}=0.98\right)$. Therefore, the difference in the weather between the EP and Lesquin airport can be considered as negligible. A small amount of precipitation was recorded between 15 June and 19 June $(14.9 \mathrm{~mm})$. From 20 June to 5 July, no rain was observed.

(a)

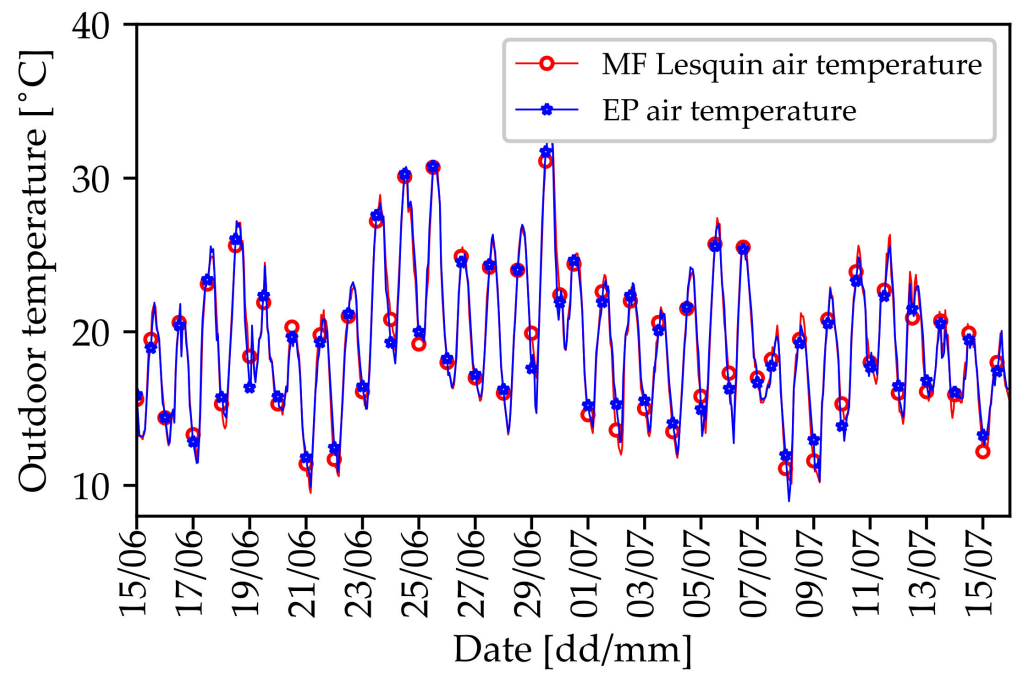

(b)

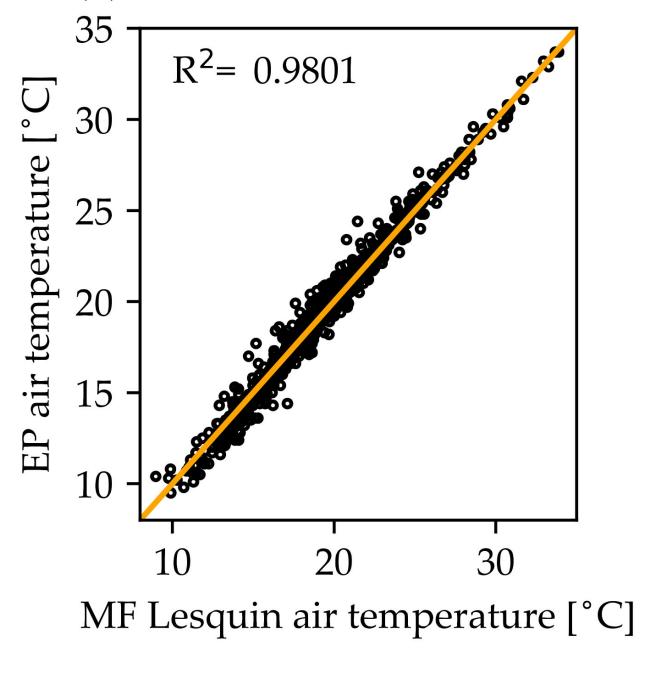

Figure 7. (a) Hourly variation of outdoor temperature (red continuous lines with round markers- ${ }^{\circ} \mathrm{C}$ ) measured by the Météo France (MF) weather station of Lesquin and hourly variation of the Experimental Platform (EP) outdoor temperature (blue continuous lines with star markers) between 15 June 2019 and 15 July 2019. (b) Comparison between the air temperatures of the EP and the MF weather station located in Lesquin. 
To gather climatic information regarding the period of interest, the weather observation datasets of Arras and Valenciennes were analyzed. These two cities are located 42 and $38 \mathrm{~km}$, respectively, from the EP (Figure 1).

Figure 8 presents weather variables for three Météo France weather stations in Lesquin, Valenciennes, and Arras during the study period (24 June to 30 June 2019). During this period, global irradiance (experimental error of $\pm 7 \mathrm{~W} \cdot \mathrm{m}^{-2}$ ) increased to $300 \mathrm{~W} \mathrm{~m}^{-2}$, except for 30 June (cloudy day), when the radiation was less than $250 \mathrm{~W} \mathrm{~m}^{-2}$ and recorded drops to between 100 and $130 \mathrm{~W} \mathrm{~m}^{-2}$ (Figure $8 \mathrm{~b}$ ). Air temperatures were very similar $\left(1-2{ }^{\circ} \mathrm{C}\right.$ difference) between the three cities (Figure 8a). Based on this similarity in terms of outdoor temperature, it can be hypothesized that the global downward solar radiation is similar at the Météo France weather station of Valenciennes and the Experimental Platform of Lesquin.

(a)

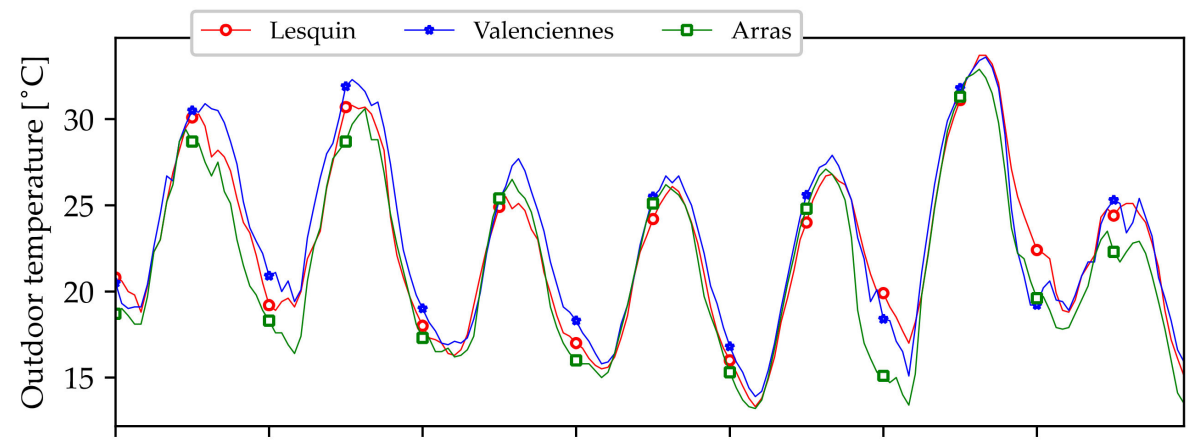

(b)

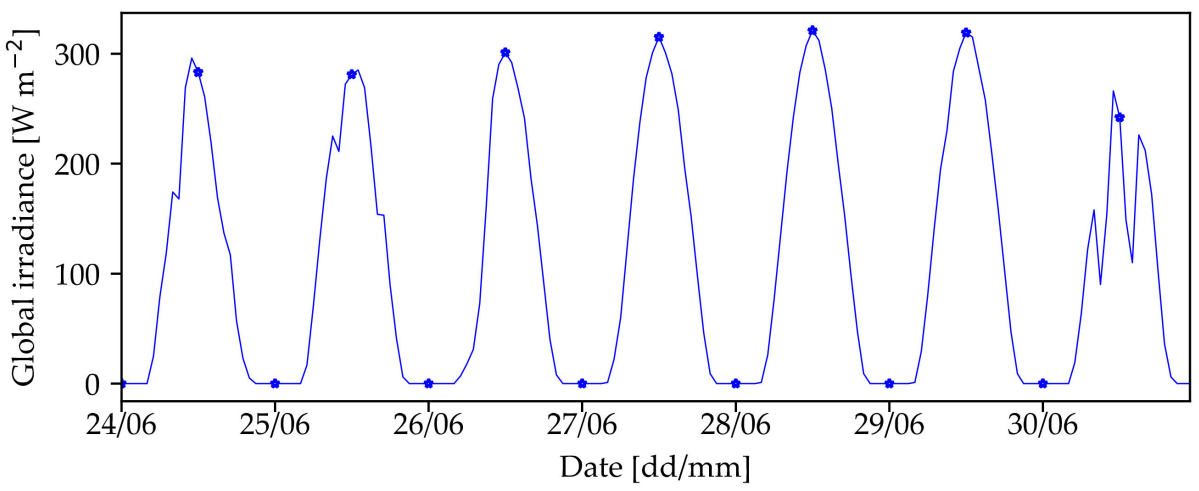

Figure 8. (a) Outdoor temperature representation of the three different Météo France weather stations: Valenciennes $\left(50^{\circ} 21^{\prime} 36^{\prime \prime} \mathrm{N} 3^{\circ} 05^{\prime} 24^{\prime \prime} \mathrm{E}\right)$, Arras $\left(50^{\circ} 15^{\prime} 36^{\prime \prime} \mathrm{N} 2^{\circ} 52^{\prime} 12^{\prime \prime} \mathrm{E}\right)$, and Lesquin $\left(50^{\circ} 20^{\prime} 24^{\prime \prime} \mathrm{N}\right.$ $3^{\circ} 04^{\prime} 12^{\prime \prime}$ E) between 24 June 2019 and 30 June 2019. (b) Global downward irradiance of the Valenciennes $\left(50^{\circ} 21^{\prime} 36^{\prime \prime} \mathrm{N} 3^{\circ} 05^{\prime} 24^{\prime \prime} \mathrm{E}\right)$ weather station between 24 June 2019 and 30 June 2019.

The frequency distribution of wind speed and wind direction between 24 June 2019 and 30 June 2019 are presented in Figure 9 for different Météo France weather stations: Lesquin (a)-(b), Valenciennes (c)-(d), and Arras (e)-(f). The prevailing wind is North-East for the three cities. The mean wind speeds are between 4 and $4.5 \mathrm{~m} \mathrm{~s}^{-1}$ for all locations. The most frequent wind speed is $4.5 \mathrm{~m} \mathrm{~s}^{-1}$ for Lesquin (frequency $11.2 \%$ ), $4.5 \mathrm{~m} \mathrm{~s}^{-1}$ for Valenciennes (frequency 10.5\%), and $4.8 \mathrm{~m} \mathrm{~s}^{-1}$ for Arras (frequency 13.0\%). As in the case of the temperature, the wind profiles of these three weather stations were very close. 


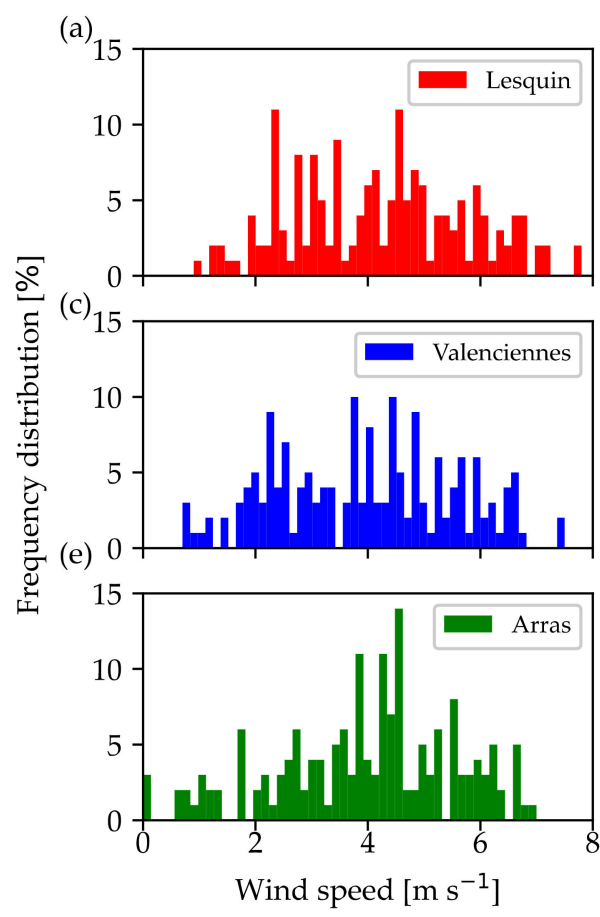

(b)

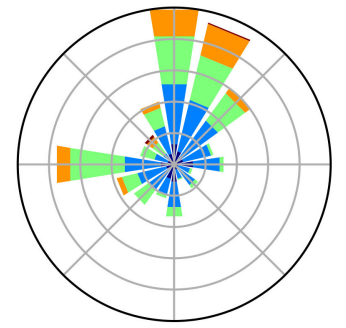

(d)

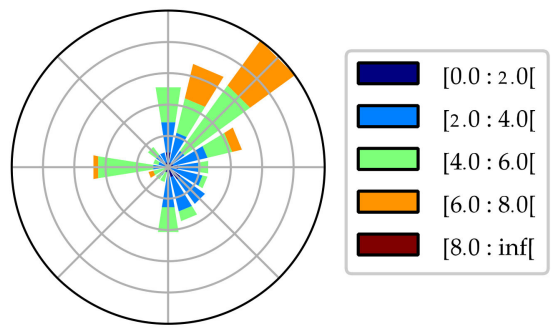

Figure 9. Frequency distribution of wind speed for: (a) Météo France (Lesquin-50 $20^{\prime} 24^{\prime \prime} \mathrm{N}$ $\left.3^{\circ} 04^{\prime} 12^{\prime \prime} \mathrm{E}\right),(\mathbf{c})$ Météo France weather station at Valenciennes $\left(50^{\circ} 21^{\prime} 36^{\prime \prime} \mathrm{N} 3^{\circ} 05^{\prime} 24^{\prime \prime} \mathrm{E}\right)$, and (e) Météo France weather station at Arras $\left(50^{\circ} 15^{\prime} 36^{\prime \prime} \mathrm{N} 2^{\circ} 52^{\prime} 12^{\prime \prime} \mathrm{E}\right)$. Wind direction distribution for: (b) Météo France weather station at Lesquin, (d) Météo France weather station at Valenciennes, and (f) Météo France weather station at Arras. All data were recorded between 24 June 2019 and 30 June 2019.

\section{Results}

\subsection{Impact of Depth on Temperature Dynamics}

Temporal variations of temperature of the parking lots (P1, P3, P4, and P5) and control zone (CZ9) at $-3,-8,-16,-24$, and $-55 \mathrm{~cm}$ depths between 24 June and 30 June are shown in Figure 10. In general, the daily amplitude of temperature variations tended to decrease with increasing depth. The outdoor air temperature varied between 13.4 and $33.8^{\circ} \mathrm{C}$ during this period. Temperatures at $-3 \mathrm{~cm}$ were higher than the outdoor air temperature for all parking systems.

For the depth of $-3 \mathrm{~cm}$ (Figure 10a), P3 was the warmest area during daytime and reached a maximum temperature of $51.0^{\circ} \mathrm{C}$. This confirms the existence of an energy storage effect, which induces an increase in the temperature. P3 also exhibited the highest daily temperature amplitude.

At a depth of $-3 \mathrm{~cm}, \mathrm{P} 1$ was the second warmest area during daytime and the warmest area during nighttime. For this depth, P1 was the warmest parking lot on average during the week $\left(33.1^{\circ} \mathrm{C}\right)$.

The temperature fluctuations of $\mathrm{P} 4$ (vegetation and substrate) recorded at a depth of $-3 \mathrm{~cm}$ demonstrated a similar pattern to that of P5 (wood chips) on the first day. A difference in temperature between $\mathrm{P} 4$ and P5 began to occur on the third day $\left(3-4{ }^{\circ} \mathrm{C}\right.$ at noon). This small temperature gap may be explained by the hydrophilic properties of wood chips (considered to be an organic mulching) because wood may capture part of the morning dew.

CZ9 with grass and natural soil was the coolest area during most parts of the day. The lowest surface temperatures were recorded for CZ9 (29.6 to $32.9^{\circ} \mathrm{C}$ at noon).

The depths of $-8,-16$, and $-24 \mathrm{~cm}$ demonstrated similar patterns (Figure 10b-d). P1 was the warmest area at all times (day and night). P3 and P4 were cooler than P1, and P5 
and CZ9 were the coolest areas. P3 tended to be warmer than P4 during daytime, but the two lots exhibited similar minimum temperatures. P5 and CZ9 showed almost identical thermal behavior. Each PLT presented a repeatable daily temperature pattern.

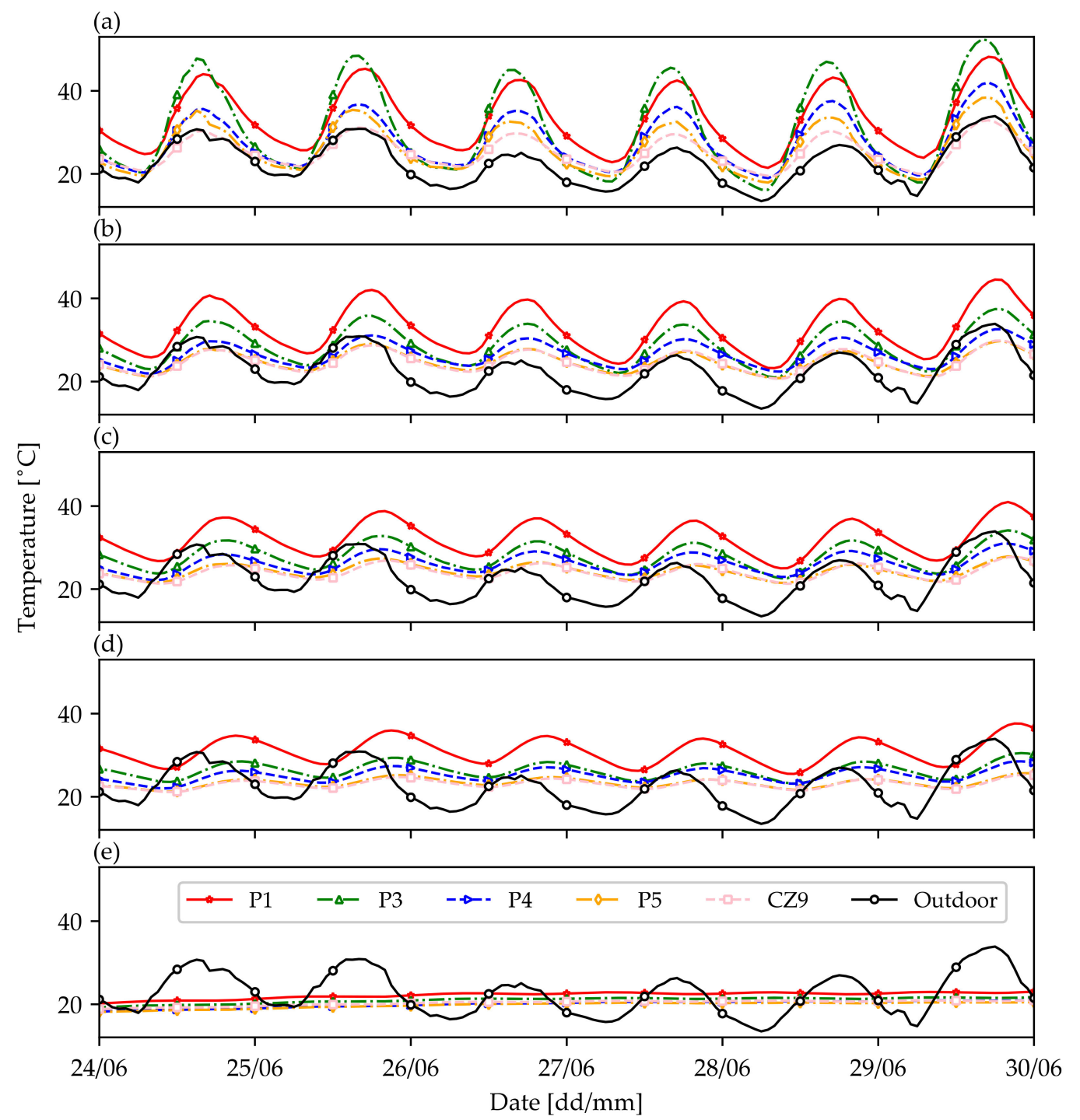

Figure 10. Temperature records at different depths: $-3 \mathrm{~cm}(\mathbf{a}) ;-8 \mathrm{~cm}(\mathbf{b}) ;-16 \mathrm{~cm}(\mathbf{c}) ;-24 \mathrm{~cm}(\mathbf{d})$; $-55 \mathrm{~cm}$ (e) during the summer period from 24 June to 30 June 2019. P1 is represented with a red solid line with star markers. P3 is represented with a green dotted line with triangle up markers. P4 is represented with a blue dotted line with triangle right markers. P5 is represented with an orange dotted line with diamond markers. CZ9 is represented with a pink dashed line with square markers. The black continuous line with round markers represents air ambient temperature.

Measurements at a depth of $55 \mathrm{~cm}$ indicated similar patterns and described a plateau (between 18.2 and $22.7^{\circ} \mathrm{C}$ ). The amplitudes of the variations and the temporal shift, which were particularly visible on the temperature peaks, were negligible (Figure 10e).

\subsection{Analysis of the Daily Temperature Cycle}

The daily vertical heat transfer cycles were analyzed by the temperature profiles measured at different depths (Figure 11). For all systems, the depth of $-3 \mathrm{~cm}$ demonstrated the highest temperature amplitude. The temperature amplitude decreased when the depth increased. During daytime, the heat received on the surface was transferred downward by conduction to the lower layers $(-8,-16$, and $-24 \mathrm{~cm}$ depths). A daily maximum 
temperature was observed for all layers, except for the depth of $-55 \mathrm{~cm}$. However, the maximum temperature time differed between layers and time shifts were observed. The deeper the layer, the later the daily maximum temperature occurred.

At the beginning of the evening, the $-3 \mathrm{~cm}$ depth layer started to cool due to convection and radiative transfer. During all the evenings and nights, the lower layers released the stored heat, and the conduction transfer was oriented upward.

The outdoor temperature was much lower than the layer temperatures of P1 and P3 (Figure 11). In the cases of $\mathrm{P} 4$ and $\mathrm{P} 5$, the temperature at $-3 \mathrm{~cm}$ (resp. at $-8,-16$, and $-24 \mathrm{~cm}$ depths) was higher than (resp. similar to) the outdoor temperature. It appears that CZ9 exhibited a temperature at $-3 \mathrm{~cm}$ that was comparable to or slightly higher than the outdoor temperature (Figure 10).

Considering P1, the daytime conductive heat transfer toward the lower layers was fast and effective. The time shifts observed for P1 between the daily maximum temperatures $(-3,-8,-16$, and $-24 \mathrm{~cm}$ depths $)$ were the lowest of all the studied systems. Moreover, the P1 system stored solar energy in the superficial layer (second warmest daytime temperature at $-3 \mathrm{~cm}$ depth) and efficiently transferred the heat toward the sublayers (warmest daytime temperature at $-8,-16$, and $-24 \mathrm{~cm}$ depths).

P3, P4, and P5 systems included a slab at the superficial layer (between 0 and $-6 \mathrm{~cm}$ depths). Results indicate that this element played a minor role regarding the thermal behavior of PLT, because the P3 system showed a significantly different underground temperature than that of the $\mathrm{P} 4$ and $\mathrm{P} 5$ systems.

\subsection{Comparison between Studied Systems and Control Zone}

Figure 12 presents the temperature differences between each parking lot (P1, P3, P4, and P5) and the control area (CZ9) (cf. Equation (1)). In the case of P1 (Figure 12a), from a depth of -3 to $-24 \mathrm{~cm}$, an increase in depth led to a decrease in the daily amplitude and a time shift in the daily temperature extrema. At $-55 \mathrm{~cm}$ depth, the difference between P1 and CZ9 was almost negligible $\left(0\right.$ to $\left.2.0^{\circ} \mathrm{C}\right)$.

The P3 system remained cooler than P1 on average (Figure 12b) for all depths except that of $-3 \mathrm{~cm}$. The paved stone was up to $19.5^{\circ} \mathrm{C}$ warmer than the control zone during daytime but was cooler than grass during nighttime $\left(-3.5^{\circ} \mathrm{C}\right)$. The paving stone layer (P3) stored a significant amount of heat and increased its temperature. However, it transferred less heat toward the lower layers than P1.

$\mathrm{P} 4$ and P5 systems were consistently cooler than P1 $\left(0\right.$ to $\left.5.0^{\circ} \mathrm{C}\right)$ (Figure $\left.12 \mathrm{c}, \mathrm{d}\right)$. During nighttime, the temperature at a depth of $-3 \mathrm{~cm}$ was similar to that of $\mathrm{CZ} 9$. The difference in temperature reached approximately $+9.0^{\circ} \mathrm{C}$ for $\mathrm{P} 4$ and $+5.0^{\circ} \mathrm{C}$ for $\mathrm{P} 5$ during daytime. $\mathrm{P} 4$ demonstrated a positive difference in temperature for $-8,-16$, and $-24 \mathrm{~cm}$ depths (average of $2.3^{\circ} \mathrm{C}$ ), and no temperature gap for the $-55 \mathrm{~cm}$ depth. Except for the $-3 \mathrm{~cm}$ depth, the temperature differences between P5 and CZ9 were not significant.

\subsection{Cooling and Heating Rates}

The cooling and heating rates were calculated for the $-3 \mathrm{~cm}$ depth on 25 June and 26 June 2019 (cf. Equations (2) and (3)) (Figure 13). Two hours before and after sunrise, all RC rates tended to be similar (between 0.0 and $1.0^{\circ} \mathrm{Ch}^{-1}$ ). Heating started $1-2 \mathrm{~h}$ after sunrise (positive value of temperature rate, i.e., heating rate). The heating rates increased and reached their daily maximum around noon. The $-3 \mathrm{~cm}$ depth layers started to cool around $5 \mathrm{pm}$ (negative value of temperature rate, i.e., cooling rate). The daily minimum in the cooling rate was reached around sunset. 
(a)

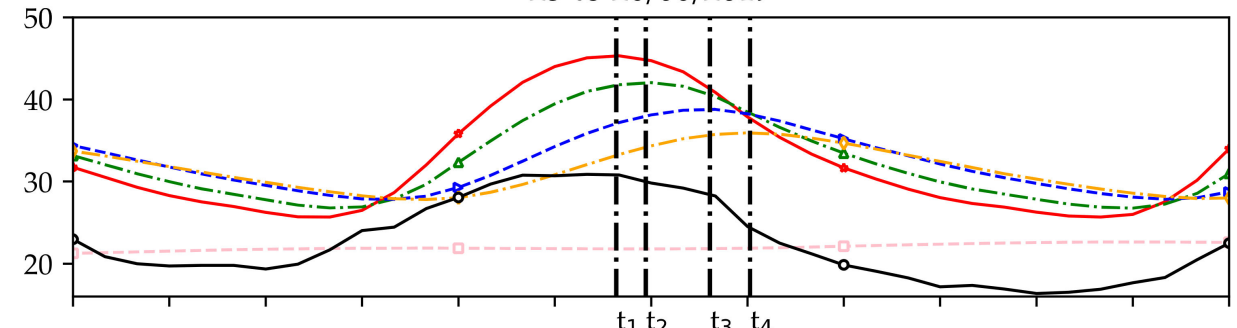

(b)

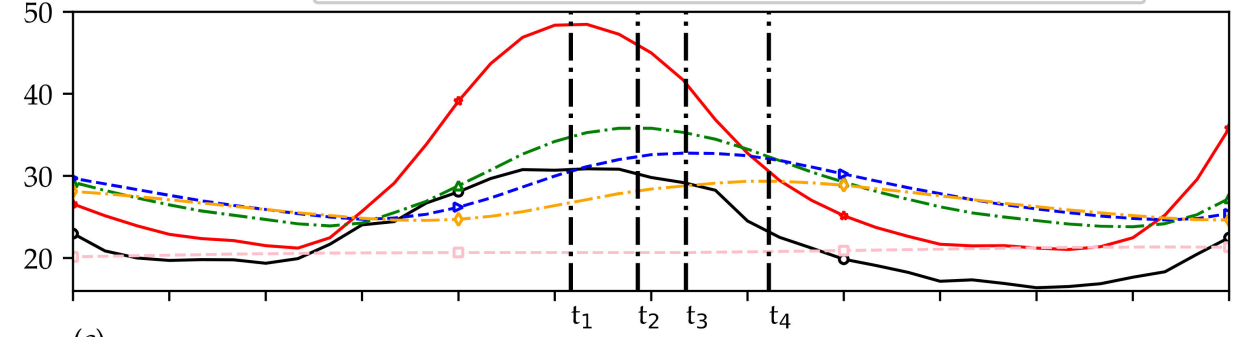

(c)

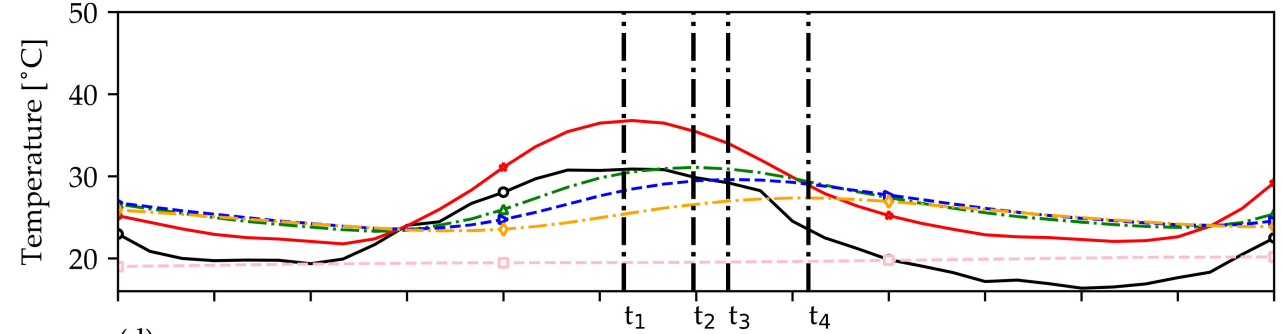

(d)

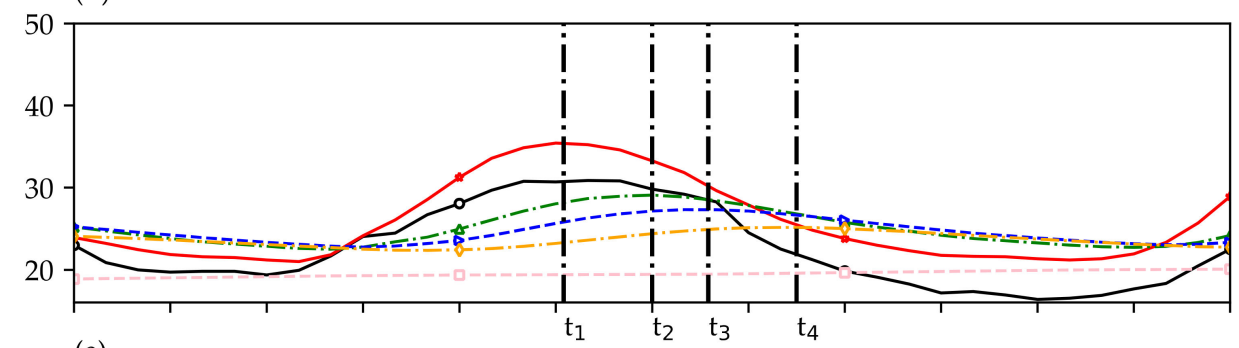

(e)

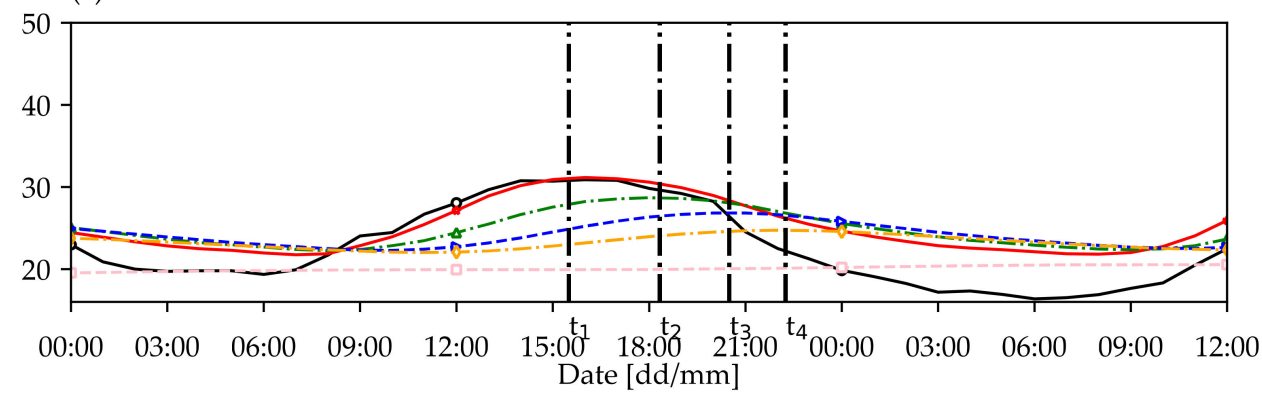

Figure 11. Representation of temperature curves at different depths for P1 (a), P3 (b), P4 (c), P5 (d), and CZ9 (e) systems from 25 June to 26 June 2019. Temperature at $-3 \mathrm{~cm}$ depth is represented with a red solid line with star markers. Temperature at $-8 \mathrm{~cm}$ depth is represented with a green dotted line with triangle up markers. Temperature at $-16 \mathrm{~cm}$ depth is represented with a blue dotted line with triangle right markers. Temperature at $-24 \mathrm{~cm}$ depth is represented with an orange dotted line with diamond markers. Temperature at $-55 \mathrm{~cm}$ depth is represented with a pink dashed line with square markers. The black continuous line with round markers represents air ambient temperature. $t_{1}$ represents maximum temperature at $-3 \mathrm{~cm}$ depth. $t_{2}$ represents maximum temperature at $-8 \mathrm{~cm}$ depth. $t_{3}$ represents maximum temperature at $-16 \mathrm{~cm}$ depth. $t_{4}$ represents maximum temperature at $-24 \mathrm{~cm}$ depth. 

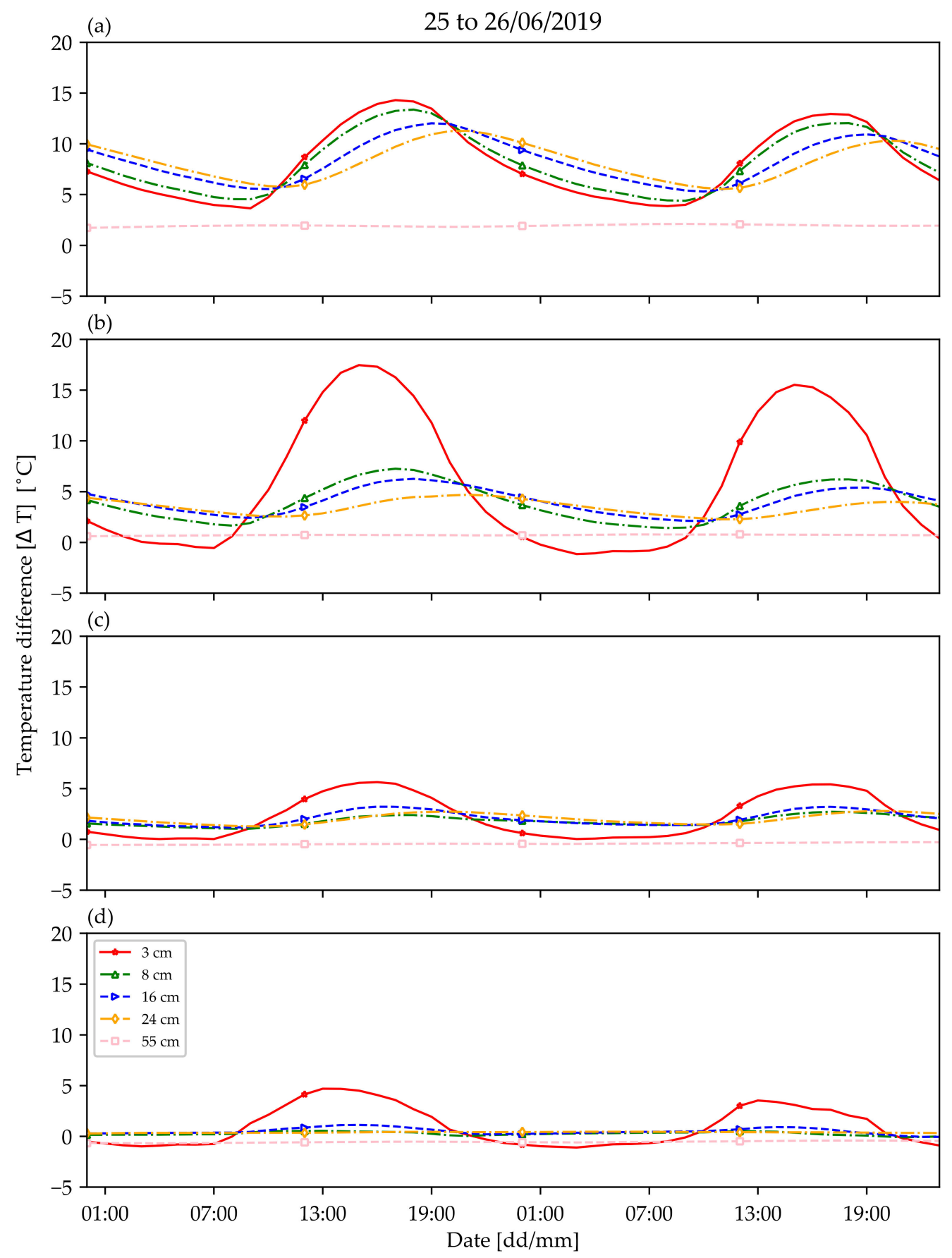

Figure 12. Representation of the temperature difference $\Delta T\left({ }^{\circ} \mathrm{C}\right)$ based on Equation (1) at the different depths for the P1 (a), P3 (b), P4 (c), and P5 (d) systems compared to the control area (CZ9) from 25 June-26 June 2019. Temperature at $-3 \mathrm{~cm}$ depth is represented with a red solid line with star markers. Temperature at $-8 \mathrm{~cm}$ depth is represented with a green dotted line with triangle up markers. Temperature at $-16 \mathrm{~cm}$ depth is represented with a blue dotted line with triangle right markers. Temperature at $-24 \mathrm{~cm}$ depth is represented with an orange dotted line with diamond markers. Temperature at $-55 \mathrm{~cm}$ depth is represented with a pink dashed line with square markers. 


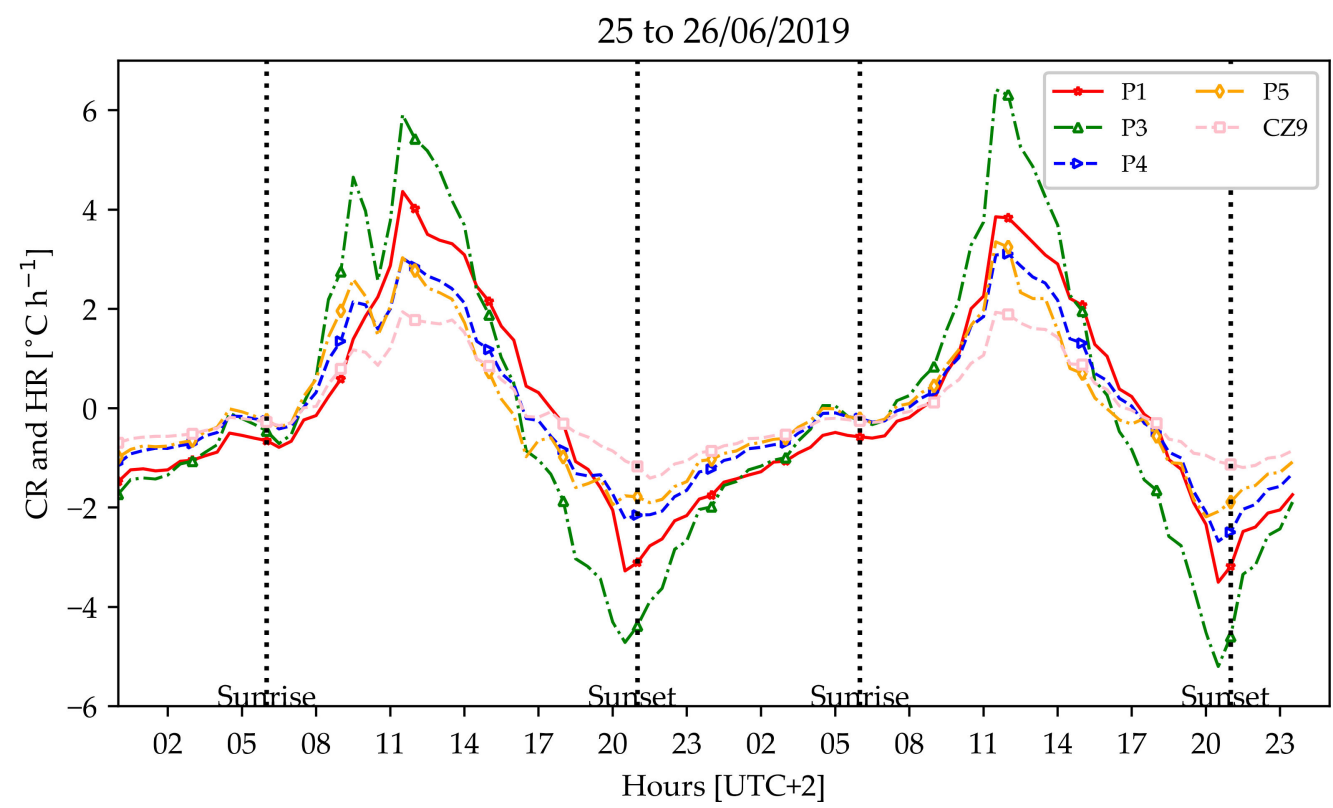

Figure 13. Representation of the rate of change (RC) $\left({ }^{\circ} \mathrm{C} \mathrm{h}^{-1}\right)$ in five PLTs at $-3 \mathrm{~cm}$ depth (25 to 26 June 2019). P1 is represented with a red solid line with star markers. P3 is represented with a green dotted line with triangle up markers. P4 is represented with a blue dotted line with triangle right markers. P5 is represented with an orange dotted line with diamond markers. CZ9 is represented with a pink dashed line with square markers.

Results illustrate that P3 had the highest RC (corresponded to the heating phase during daytime (up to $6.0^{\circ} \mathrm{Ch}^{-1}$ at noon, UTC +2 ) and the lowest RC during nighttime $\left(-5.0^{\circ} \mathrm{C} \mathrm{h}^{-1}\right.$ ). P1 demonstrated less intense temperature rates than P3 (maximum RC $4.0^{\circ} \mathrm{C} \mathrm{h}^{-1}$, minimum $\mathrm{RC}-3.0^{\circ} \mathrm{C} \mathrm{h}^{-1}$ ). The $\mathrm{P} 4$ and $\mathrm{P} 5$ systems had very similar thermal behavior during both day and night. The RC of P4 was, on average, $0.2^{\circ} \mathrm{C} \mathrm{h}^{-1}$ higher than the temperature rate of P5. CZ9 showed the smallest amplitude of $\mathrm{RC}\left(+2.0^{\circ} \mathrm{C} \mathrm{h}^{-1}\right.$ during daytime, $-1.5^{\circ} \mathrm{Ch}^{-1}$ during nighttime).

\section{Discussion}

As stated by Hendel et al. [37], the surface material acts as a solar energy receiver and the underground material acts as a form of energy storage. In this study, several solar energy receivers were investigated. The high surface temperature reached by the asphalt cover (P1) is in line with the work of Ca et al. [48], who studied the impact of asphalt paved parking lots in Tokyo, Japan, during the warm period (August to September 1994). Results highlight that the surface temperature at noon rose to $55^{\circ} \mathrm{C}$. Therefore, the solution with asphalt causes an increase in the adjacent air temperature through sensible heat release [49].

The results show the capacity of the paving stone to store a remarkable amount of heat during daytime, and to release it rapidly during the evening and night [50]. Qin and Hiller [51] conducted an experimental study on the pavement-surface energy balance in the Mediterranean climate of dry, hot summers in Davis, California, USA. In this study, most of the absorbed solar energy was transferred into the material via thermal conduction.

The grass cover of $\mathrm{P} 4$ and CZ9 appears to be beneficial to the thermal behavior. The presence of vegetation may attenuate the daily amplitude of the temperature $[52,53]$.

Foundations play a role in thermal storage. From a depth of 24 to $55 \mathrm{~cm}$, the foundations of P1, P3, P4, and P5 systems were mineral. As a result, the heat transfer from the surface to the underlying layers was reduced due to the low energy storage capacity of the gravel $[51,54,55]$.

This experimental study suggests that improvements can be undertaken on several PLTs. A modification of the paving stone color (P3) and slab color (P3, P4, and P5) would 
impact their albedo and may reduce the peak daytime temperature. For instance, Wang and Akbari [56] showed that higher albedo paving can reduce the UHI effect during the day.

\section{Conclusions}

This study investigated the reaction of pervious pavement, such as green parking lots, in terms of thermal behavior during warm and dry weather conditions. It compared the thermal behavior of different parking lot types (PLTs): a conventional asphalt parking lot (P1), a grass-covered natural soil (CZ9), and three alternative parking lot systems (concrete paving stone (P3), grass-covered slab filled with a mix of soil and sand (P4), and slab filled with wood chips (P5); the latter lots are considered as green parking lots (GPLs)). Results underline that the less mineral the surface coating, the less it warms up. The temperature difference at the upper layer can reach $10^{\circ} \mathrm{C}$ between mineral and non-mineral PLTs.

It was found that P1 is the least appropriate modality in an urban heat island context: it heats up quickly, reaches very high temperatures, and transmits heat to the deeper layers of soil. P3 is an intermediate solution. It heats up very quickly and reaches high temperatures that warm the boundary layer. It also cools very quickly and does not store heat over several days. The two solutions that provide results closest to the thermal behavior of natural soils are the P4 and P5 solutions. The lawn became partially dried during this study, which clearly reduced the action of vegetation on soil temperature.

This study highlights that the parking lots systems can be grouped into three types: (i) high surface temperature during daytime, moderate temperature during nighttime, important heat transfer toward the sublayers, and low time shift (P1); (ii) high surface temperature during daytime, low temperature during nighttime, weak heat transfer toward the sublayers, and important time shift (P3); and (iii) low surface temperature during daytime, low temperature during nighttime, weak heat transfer toward the sublayers, and important time shift (vegetation and substrate P4, wood chips P5, control zone CZ9). This highlights that pervious pavements demonstrate thermal benefits during warm and dry periods compared to conventional parking lot solutions. In these weather conditions, GPLs including vegetation or wood chips can obtain thermal performances close to those of grass-covered areas with silty soil.

Results provide insights into how alternative parking lots can affect atmospheric and underground urban heat islands. Because the size of parking lots may range from hundreds to thousands of square meters, urban materials and innovative parking lot solutions need to be assessed in real conditions before being installed at a larger scale. Moreover, the thermal behavior of PLTs should be investigated under warm and dry weather conditions, which are likely to be frequently observed in the coming decades. The output of this research can be valuable for modelling purposes, which is also an important field of climate-smart urban decision making. Subsurface heat transfer for nontraditional solutions must be better understood and modelled. The experimental results presented in this study are worthy to be integrated into numerical modelling approaches.

Author Contributions: Conceptualization, F.L., C.P. and S.D.; Data curation, R.B., F.L., M.P. (Margaux Pierret) and J.B.; Formal analysis, R.B., F.L., M.P. (Margaux Pierret), C.P., S.D., B.L., Z.A. and T.V.W.; Funding acquisition, F.L., C.P., S.D., B.L. and J.B.; Investigation, F.L., M.P. (Margaux Pierret), C.P., S.D., B.L. and J.B.; Methodology, F.L., M.P. (Margaux Pierret), C.P., S.D. and B.L.; Project administration, F.L., C.P., S.D., B.L. and J.B.; Resources, M.K., M.P. (Margaux Pierret), T.V.W., R.G., B.C., A.P., P.L. and M.P. (Mathieu Pétrissans); Supervision, F.L. and J.B.; Validation, F.L., Z.A., T.V.W., R.G. and B.C.; Visualization, R.B.; Writing—original draft, R.B. and F.L.; Writing-review \& editing, R.B., F.L., M.K., C.P., S.D., B.L., J.B., Z.A., T.V.W., R.G. and B.C. All authors have read and agreed to the published version of the manuscript.

Funding: This research was funded by ADEME under the initiative IPME 2016 Eau $\mathcal{E}$ Milieux Aquatiques, grant number 1782C0085.

Institutional Review Board Statement: Not applicable.

Informed Consent Statement: Not applicable. 
Data Availability Statement: Not applicable.

Acknowledgments: All the authors would like to thank the anonymous reviewers for their comments and suggestions, which helped to improve the quality of the manuscript.

Conflicts of Interest: The authors have submitted a declaration of competing interests to the editors.

\section{References}

1. Danh, L.T.; Truong, P.; Mammucari, R.; Foster, N. A Critical Review of the Arsenic Uptake Mechanisms and Phytoremediation Potential of Pteris Vittata. Int. J. Phytoremed. 2014, 16, 429-453. [CrossRef]

2. Di Sabatino, S.; Barbano, F.; Brattich, E.; Pulvirenti, B. The Multiple-Scale Nature of Urban Heat Island and Its Footprint on Air Quality in Real Urban Environment. Atmosphere 2020, 11, 1186. [CrossRef]

3. Cai, D.; Fraedrich, K.; Guan, Y.; Guo, S.; Zhang, C.; Zhu, X. Urbanization and Climate Change: Insights from Eco-Hydrological Diagnostics. Sci. Total Environ. 2019, 647, 29-36. [CrossRef]

4. Cai, Y.; Zhang, H.; Zheng, P.; Pan, W. Quantifying the Impact of Land Use/Land Cover Changes on the Urban Heat Island: A Case Study of the Natural Wetlands Distribution Area of Fuzhou City, China. Wetlands 2016, 36, 285-298. [CrossRef]

5. Estoque, R.C.; Murayama, Y.; Myint, S.W. Effects of Landscape Composition and Pattern on Land Surface Temperature: An Urban Heat Island Study in the Megacities of Southeast Asia. Sci. Total Environ. 2017, 577, 349-359. [CrossRef]

6. Kikon, N.; Singh, P.; Singh, S.K.; Vyas, A. Assessment of Urban Heat Islands (UHI) of Noida City, India Using Multi-Temporal Satellite Data. Sustain. Cities Soc. 2016, 22, 19-28. [CrossRef]

7. Fan, C.; Myint, S.W.; Zheng, B. Measuring the Spatial Arrangement of Urban Vegetation and Its Impacts on Seasonal Surface Temperatures. Prog. Phys. Geogr. Earth Environ. 2015, 39, 199-219. [CrossRef]

8. Mathew, A.; Khandelwal, S.; Kaul, N. Investigating Spatial and Seasonal Variations of Urban Heat Island Effect over Jaipur City and Its Relationship with Vegetation, Urbanization and Elevation Parameters. Sustain. Cities Soc. 2017, 35, 157-177. [CrossRef]

9. Buyantuyev, A.; Wu, J. Urban Heat Islands and Landscape Heterogeneity: Linking Spatiotemporal Variations in Surface Temperatures to Land-Cover and Socioeconomic Patterns. Landsc. Ecol. 2010, 25, 17-33. [CrossRef]

10. Jalan, S.; Sharma, K. Spatio-Temporal Assessment of Land Use/Land Cover Dynamics and Urban Heat Island of Jaipur City Using Satellite Data. ISPRS Int. Arch. Photogramm. Remote Sens. Spat. Inf. Sci. 2014, 8, 767-772. [CrossRef]

11. Bouzouidja, R.; Cannavo, P.; Bodénan, P.; Gulyás, Á.; Kiss, M.; Kovács, A.; Béchet, B.; Chancibault, K.; Chantoiseau, E.; Bournet, P.-E.; et al. How to Evaluate Nature-Based Solutions Performance for Microclimate, Water and Soil Management Issues. Available Tools and Methods from Nature4Cities European Project Results. Ecol. Indic. 2021, 125, 107556. [CrossRef]

12. Zölch, T.; Henze, L.; Keilholz, P.; Pauleit, S. Regulating Urban Surface Runoff through Nature-Based Solutions-An Assessment at the Micro-Scale. Environ. Res. 2017, 157, 135-144. [CrossRef]

13. Gupta, R. Monitoring in Situ Performance of Pervious Concrete in British Columbia-A Pilot Study. Case Stud. Constr. Mater. 2014, 1, 1-9. [CrossRef]

14. Onishi, A.; Cao, X.; Ito, T.; Shi, F.; Imura, H. Evaluating the Potential for Urban Heat-Island Mitigation by Greening Parking Lots. Urban For. Urban Green. 2010, 9, 323-332. [CrossRef]

15. Park, J.-H.; Kim, J.; Yoon, D.K.; Cho, G.-H. The Influence of Korea's Green Parking Project on the Thermal Environment of a Residential Street. Habitat Int. 2016, 56, 181-190. [CrossRef]

16. Dagois, R.; Faure, P.; Bataillard, P.; Bouzouidja, R.; Coussy, S.; Leguédois, S.; Enjelvin, N.; Schwartz, C. From Atmospheric- to Pedo-Climate Modeling in Technosols: A Global Scale Approach. Geoderma 2017, 301, 47-59. [CrossRef]

17. McPherson, E.G. Sacramento's Parking Lot Shading Ordinance: Environmental and Economic Costs of Compliance. Landsc. Urban Plan. 2001, 57, 105-123. [CrossRef]

18. Chun, B.; Guldmann, J.-M. Impact of Greening on the Urban Heat Island: Seasonal Variations and Mitigation Strategies. Comput. Environ. Urban Syst. 2018, 71, 165-176. [CrossRef]

19. Takebayashi, H.; Moriyama, M. Study on the Urban Heat Island Mitigation Effect Achieved by Converting to Grass-Covered Parking. Sol. Energy 2009, 83, 1211-1223. [CrossRef]

20. Buchanan, J.R.; Yoder, D.C.; Denton, H.P.; Smoot, J.L. Wood Chips as a Soil Cover for Construction Sites with Steep Slopes. Appl. Eng. Agric. 2002, 18, 679-683. [CrossRef]

21. Wang, J.; Santamouris, M.; Meng, Q.; He, B.-J.; Zhang, L.; Zhang, Y. Predicting the Solar Evaporative Cooling Performance of Pervious Materials Based on Hygrothermal Properties. Sol. Energy 2019, 191, 311-322. [CrossRef]

22. Zhang, L.; Pan, Z.; Zhang, Y.; Meng, Q. Impact of Climatic Factors on Evaporative Cooling of Porous Building Materials. Energy Build. 2018, 173, 601-612. [CrossRef]

23. Li, Y.; Rodriguez, F.; Berthier, E. Development of the Integrated Urban Hydrological Model URBS: Introduction and Evaluation of a Transfer Module in the Saturated Zone; ICUD: Kuching, Malaysia, 2014.

24. Faisal, G.H.; Jaeel, A.J.; Al-Gasham, T.S. BOD and COD Reduction Using Porous Concrete Pavements. Case Stud. Constr. Mater. 2020, 13, e00396. [CrossRef]

25. Nemirovsky, E.M.; Welker, A.L.; Lee, R. Quantifying Evaporation from Pervious Concrete Systems: Methodology and Hydrologic Perspective. J. Irrig. Drain. Eng. 2013, 139, 271-277. [CrossRef] 
26. Wang, J.; Meng, Q.; Tan, K.; Zhang, L.; Zhang, Y. Experimental Investigation on the Influence of Evaporative Cooling of Permeable Pavements on Outdoor Thermal Environment. Build. Environ. 2018, 140, 184-193. [CrossRef]

27. Kottek, M.; Grieser, J.; Beck, C.; Rudolf, B.; Rubel, F. World Map of the Köppen-Geiger Climate Classification Updated. Meteorol. Z. 2006, 15, 259-263. [CrossRef]

28. Météo France Climate Records over the 1981-2010 Period. Technical Report [online]. Paris: Météo France. 2020, 2p. Available online: https: / / donneespubliques.meteofrance.fr/?fond=produit\&id_produit=117\&id_rubrique=39 (accessed on 1 July 2021).

29. Leconte, F.; Bouyer, J.; Claverie, R.; Pétrissans, M. Using Local Climate Zone Scheme for UHI Assessment: Evaluation of the Method Using Mobile Measurements. Build. Environ. 2015, 83, 39-49. [CrossRef]

30. Caluwaerts, S.; Hamdi, R.; Top, S.; Lauwaet, D.; Berckmans, J.; Degrauwe, D.; Dejonghe, H.; de Ridder, K.; de Troch, R.; Duchêne, F.; et al. The Urban Climate of Ghent, Belgium: A Case Study Combining a High-Accuracy Monitoring Network with Numerical Simulations. Urban Clim. 2020, 31, 100565. [CrossRef]

31. De Munck, C.; Lemonsu, A.; Bouzouidja, R.; Masson, V.; Claverie, R. The GREENROOF Module (v7. 3) for Modelling Green Roof Hydrological and Energetic Performances within TEB. Geosci. Model Dev. 2013, 6, 1941-1960. [CrossRef]

32. Mohajerani, A.; Bakaric, J.; Jeffrey-Bailey, T. The Urban Heat Island Effect, Its Causes, and Mitigation, with Reference to the Thermal Properties of Asphalt Concrete. J. Environ. Manag. 2017, 197, 522-538. [CrossRef]

33. Luca, J.; Mrawira, D. New Measurement of Thermal Properties of Superpave Asphalt Concrete. J. Mater. Civ. Eng. 2005, 17, 72-79. [CrossRef]

34. Parison, S.; Hendel, M.; Grados, A.; Royon, L. Analysis of the Heat Budget of Standard, Cool and Watered Pavements under Lab Heat-Wave Conditions. Energy Build. 2020, 228, 110455. [CrossRef]

35. Pomianowski, M.; Heiselberg, P.; Jensen, R.L.; Cheng, R.; Zhang, Y. A New Experimental Method to Determine Specific Heat Capacity of Inhomogeneous Concrete Material with Incorporated Microencapsulated-PCM. Cem. Concr. Res. 2014, 55, 22-34. [CrossRef]

36. Binici, H.; Aksogan, O. Eco-Friendly Insulation Material Production with Waste Olive Seeds, Ground PVC and Wood Chips. J. Build. Eng. 2016, 5, 260-266. [CrossRef]

37. Hendel, M.; Parison, S.; Grados, A.; Royon, L. Which Pavement Structures Are Best Suited to Limiting the UHI Effect? A Laboratory-Scale Study of Parisian Pavement Structures. Build. Environ. 2018, 144, 216-229. [CrossRef]

38. Santa, G.D.; Peron, F.; Galgaro, A.; Cultrera, M.; Bertermann, D.; Mueller, J.; Bernardi, A. Laboratory Measurements of Gravel Thermal Conductivity: An Update Methodological Approach. Energy Procedia 2017, 125, 671-677. [CrossRef]

39. Zhang, N.; Wang, Z. Review of Soil Thermal Conductivity and Predictive Models. Int. J. Therm. Sci. 2017, 117, 172-183. [CrossRef]

40. Lu, S.; Ren, T.; Gong, Y.; Horton, R. An Improved Model for Predicting Soil Thermal Conductivity from Water Content at Room Temperature. Soil Sci. Soc. Am. J. 2007, 71, 8-14. [CrossRef]

41. Holmer, B.; Thorsson, S.; Eliasson, I. Cooling Rates, Sky View Factors and the Development of Intra-urban Air Temperature Differences. Geogr. Ann. Ser. A Phys. Geogr. 2007, 89, 237-248. [CrossRef]

42. Konarska, J.; Holmer, B.; Lindberg, F.; Thorsson, S. Influence of Vegetation and Building Geometry on the Spatial Variations of Air Temperature and Cooling Rates in a High-Latitude City. Int. J. Climatol. 2016, 36, 2379-2395. [CrossRef]

43. Leconte, F.; Bouyer, J.; Claverie, R. Nocturnal Cooling in Local Climate Zone: Statistical Approach Using Mobile Measurements. Urban Clim. 2020, 33, 100629. [CrossRef]

44. Milošević, D.; Savić, S.; Kresoja, M.; Lužanin, Z.; Šećerov, I.; Arsenović, D.; Dunjić, J.; Matzarakis, A. Analysis of Air Temperature Dynamics in the "Local Climate Zones" of Novi Sad (Serbia) Based on Long-Term Database from an Urban Meteorological Network. Int. J. Biometeorol. 2021. [CrossRef]

45. Bland, J.M.; Altman, D.G. Statistics Notes: Measurement Error. BMJ 1996, 312, 1654. [CrossRef] [PubMed]

46. Van Oldenborgh, G.J.; Vautard, R.; Boucher, O.; Otto, F.; Haustein, K.; Soubeyroux, J.M.; Seneviratne, S.I.; Vogel, M.M.; Aalst, M.; Stott, P. Human Contribution to the Record-Breaking June 2019 Heat Wave in France. Available online: https: //www.worldweatherattribution.org/human-contribution-to-record-breaking-june-2019-heatwave-in-france/ (accessed on 10 December 2020).

47. Zhao, W.; Zhou, N.; Chen, S. The Record-Breaking High Temperature over Europe in June of 2019. Atmosphere 2020, 11, 524. [CrossRef]

48. Ca, V.T.; Asaeda, T.; Abu, E.M. Reductions in Air Conditioning Energy Caused by a Nearby Park. Energy Build. 1998, $29,83-92$. [CrossRef]

49. Khalifa, A.; Bouzouidja, R.; Marchetti, M.; Buès, M.; Bouilloud, L.; Martin, E.; Chancibaut, K. Individual Contributions of Anthropogenic Physical Processes Associated to Urban Traffic in Improving the Road Surface Temperature Forecast Using TEB Model. Urban Clim. 2018, 24, 778-795. [CrossRef]

50. Lin, Y.; Ichinose, T. Experimental Evaluation of Mitigation of Thermal Effects by "Katsuren Travertine" Paving Material. Energy Build. 2014, 81, 253-261. [CrossRef]

51. Qin, Y.; Hiller, J.E. Understanding Pavement-Surface Energy Balance and Its Implications on Cool Pavement Development. Energy Build. 2014, 85, 389-399. [CrossRef]

52. Santamouris, M. Using Cool Pavements as a Mitigation Strategy to Fight Urban Heat Island-A Review of the Actual Developments. Renew. Sustain. Energy Rev. 2013, 26, 224-240. [CrossRef] 
53. Ugolini, F.; Baronti, S.; Lanini, G.M.; Maienza, A.; Ungaro, F.; Calzolari, C. Assessing the Influence of Topsoil and Technosol Characteristics on Plant Growth for the Green Regeneration of Urban Built Sites. J. Environ. Manag. 2020, 273, 111168. [CrossRef]

54. Sailor, D.J.; Hagos, M. An Updated and Expanded Set of Thermal Property Data for Green Roof Growing Media. Energy Build. 2011, 43, 2298-2303. [CrossRef]

55. Yavuzturk, C.; Ksaibati, K.; Chiasson, A.D. Assessment of Temperature Fluctuations in Asphalt Pavements Due to Thermal Environmental Conditions Using a Two-Dimensional, Transient Finite-Difference Approach. J. Mater. Civ. Eng. 2005, 17, 465-475. [CrossRef]

56. Wang, Y.; Akbari, H. Analysis of Urban Heat Island Phenomenon and Mitigation Solutions Evaluation for Montreal. Sustain. Cities Soc. 2016, 26, 438-446. [CrossRef] 